

\section{ADVANTAGES AND DISADVANTAGES OF THE VIRTUAL LEARNING ENVIRONMENT IN UKRAINIAN AS A FOREIGN LANGUAGE FOR 2ND YEAR STUDENTS OF TECHNICAL UNIVERSITIES}

The article highlights the main advantages and disadvantages of the implementation of the Virtual Learning Environment (VNS) during distance learning of Ukrainian as a foreign language (UFL) in a group of second-year foreign students at the National University "Lviv Polytechnic". The focus is on clarity and consistency in the presentation and use of textbooks and manuals on UFL, the use of tasks and exercises for different types of speech activities: listening, reading, writing, speaking. Possible programs for distance learning and methods of information transfer during virtual learning are described. The definition of distance learning in the VNS as one of the forms of realization of interdisciplinary connections and integration of knowledge in several subjects is clearly outlined. It is also a means of increasing the motivation to study the subject, as they create conditions for the practical application of knowledge; develop self-education skills, because most of the preparation for classes foreign students carry out independently and in extracurricular activities; online classes transfer skills to new areas that have not been studied before, which helps students make decisions about creative production situations. An unconventional type of lesson is considered, which is rather one of the forms of the project, which allows to integrate knowledge from different areas to solve one problem. The article presents important principles of understanding, mastering and accumulation of vocabulary on the basis of popular science and technical texts, which are the basis for the development of analytical skills, ingenuity and competence of foreign students. Various types of falls have been proposed for the study of the Ukrainian language in a foreign language environment. Examples of exercises for writing and reading are described with examples that help foreign students to learn the vocabulary of the Ukrainian language. There are also samples of tasks that were difficult to work with in a practical lesson in a group of second-year students at the National University "Lviv Polytechnic". The focus is on the problems of teaching Ukrainian as a foreign language in technical universities. The article presents observations on the use of modern pedagogical technologies as a form of learning organization.

Key words: Ukrainian as a foreign language, online tutorials, distance learning, integration of knowledge, popular science texts, foreign language environment.

Постановка проблеми. Сучасні потреби вивчення української мови як іноземної в технічних вишах пов'язані, насамперед, із розвитком та збереженням української мови, якісною розбудовою українського мовного простору та пошуком нових методів викладу і подачі мовного матеріалу студентам-іноземцям (Лещенко, 2013: 253). Наголосімо, що вивчення мови - це важкий і кропіткий процес. Кожен, хто вчиться та навчає, шукає якомога ефективніші методи іiі засвоєння та подачі. ВНС Національного університету «Львівська політехніка» стало значним кроком уперед, зокрема у пошуках нових методів вивчення української мови як іноземної у технічних вишах. Саме такий пошук та впровадження сучасних педагогічних технологій як форми організації навчання та поєднання теорії і практики є завданням кожного 3 нас. Це дозволить інтегрувати знання з різних областей для рішення однієї проблеми, для застосування отриманих знань на практиці (Мельник, 2015: 1).

Аналіз останніх досліджень і публікацій. Реалізація дистанційного навчання в Україні - дуже неоднорідна. Чимало викладачів та студентів прийняли новий виклик і справляються з ним, проте $\epsilon$ й такі, котрим він не під силу, адже не мають для цього необхідних технічних засобів, знань, навичок чи навіть бажання. Дистанційне навчання стало для українських закладів освіти загалом i педагогів зокрема перевіркою на те, як швидко вони можуть реагувати на ці виклики, наскільки здатні бути гнучкими та ефективними у некомфортних умовах, а також на комп'ютерну грамотність та вміння працювати на сучасних освітніх 
онлайн-платформах. Основою ефективного дистанційного навчання $є$ самоорганізація студентів, бажання вчитися, не зважаючи ні на що. А саме із цим $\epsilon$ проблеми: низька мотивація до навчання у студентів українських вишів - справжня больова точка (Мончук, 2020: 1).

Навчання під час онлайн-занять (не тільки 3 української мови) в іншомовній аудиторії питання досить поширене і часто досліджуване. У процесі вивчення української мови як іноземної особливої уваги потребує засвоєння її лексики та термінології, зокрема тієї галузі, фахівцем з якої готується стати студент. Тому дослідження методик опрацювання зі студентами-іноземцями української термінології є актуальнимі дужепотрібним, вважає 3. Й. Куньч (Куньч, 2008: 198). Засвоєння студентом-іноземцем української лексики та термінології свого фаху ускладнено кількома обставинами. По-перше, у процесі повсякденного спілкування іноземного студента в україномовному середовищі термінологічна лексика не звучить. По-друге, засвоєння іноземцями українських термінів викликає труднощі через невпорядкованість i недостатню усталеність окремих терміносистем. По-третє, вивчення студентом фахової мови відбувається паралельно і на онлайн-заняттях 3 української мови, і під час вивчення фахових дисциплін дистанційно. Тому засвоєння фахової термінології відбувається і під керівництвом викладача-філолога, i через лекції або коментарі викладачів фахових дисциплін. Поради і настанови різних викладачів можуть відрізнятися, і це, звичайно, не сприяє кращому засвоєнню відповідної термінолексики. По-четверте, набуваючи навичок професійної роботи під час виробничої практики, студент-іноземець може зіштовхнутися iз виробничо-професійним жаргоном, в якому певні поняття мають свої назви, відмінні від термінологічних, які часто навіть не зафіксовані ані в підручниках, ані в словниках (Куньч, 2008: 199). Одним 3 ефективних способів засвоєння української мови як іноземної є вивчення іiї лексичного складу засобами словотвору, вважає Н. Дзеньдзюра (Дзеньдзюра, 2014: 79).

Створити умови мотивованого практичного застосування знань, навичок та вмінь, дати студентам-іноземцям можливість побачити результати своєї праці і отримати від неї радість і задоволення, зацікавити їх у вивченні лексики, граматики та термінології української мови на основі науково-популярних та технічних текстів, зробити заняття захопливими, удосконалити комунікативно-пізнавальні вміння, спрямовані на систематизацію і поглиблення знань та обмін цими знаннями в умовах співробітництва, - все це мета кожного фахівця. (Козелко, 2015: 127).

Мета статті - показати, яким чином найдоступніше можна передати під час дистанційного навчання у ВНС знання з української мови як іноземної студентам та як допомогти їм засвоїти їx у найцікавіший спосіб. Дослідити можливості використання різних видів вправ та завдань до науково-популярних та технічних текстів 3 української мови в іншомовній аудиторії, розкрити одну 3 форм реалізації міжпредметних зв'язків та інтеграції знань з кількох предметів. Забезпечити можливість більш швидкого формування лексико-семантичних навичок у процесі викладання української мови іноземним студентам технічних спеціальностей; показати систему можливих методичних прийомів і матеріалів, спрямованих на вивчення лексики, граматики та термінології у найрізноманітніших програмах; вказати на шляхи реалізації комунікативного $\mathrm{i}$ функціонально-стилістичного підходів при формуванні мовної, мовленнєвої та комунікативної компетенції на заняттях 3 української мови в іншомовній аудиторії у чотирьох видах мовленнєвої діяльності.

Виклад основного матеріалу. Мова навчання це один із найважливіших критеріїв роботи, особливо для іноземних громадян. Та вивчати мову дистанційно й слухати лекцій онлайн - це складно вдвічі. У Національному університеті «Львівська політехніка» розроблена програма ВНC http://vns.lpnu.ua/, де кожен студент і викладач може отримати фахову допомогу 3 певної спеціальності. Усі навчальні програми, робочі календарні плани, теми лекційних занять, конспекти, словники та тести - все $\epsilon$ у вільному доступі. Для кожного працівника та студента створені у ВНС окремі логіни і паролі. У цій програмі чітко прописана система оцінювання та перевірки домашніх завдань і контрольних робіт. Все можна побачити у так званому «журналі оцінок», який достатньо завантажити з ВНС на будь-який пристрій та продемонструвати, чи зберегти для подальшої роботи, або перевірки. Разом із тим певним недоліком $\epsilon$ те, що програма періодично може «зависати» і не відкриватися, коли туди одночасно заходить велика кількість користувачів, а це створює додаткове навантаження на кожного викладача, який повинен швидко відреагувати на проблему та знайти рішення.

Під час карантинного періоду дистанційне навчання стало поштовхом для пізнання нових можливостей викладання і навчання не тільки для викладачів, але й для студентів. Процес обміну 
досвідом був взаємним. Все нове завжди лякає, але, разом із тим, чітко показує, хто готовий до випробувань, а хто ні.

Треба визнати, що, на жаль, для деяких іноземних студентів навчання в Україні стає суцільними перегонами. По-перше, це їхнє невміння вчитися та неорганізованість. По-друге, є окремі недоліки в організації самого навчального процесу та формуванні груп: студенти, які приїхали 3 різних країн та ще й $з$ певною різницею у часі, не можуть «на старті» мати однаковий рівень підготовки, але часто зараховуються в одну навчальну групу. По-третє, присутня думка про тимчасовість самого перебування в університеті. Чимало студентів планує у подальшому виїхати в третю країну, можливо навіть поміняти спеціальність, а як результат, - небажання вникати не лише у побут, звичаї та культуру України, але й у сам навчальний процес: вкладати у нього час, виконувати завдання, купляти книги, посібники тощо. Практика дистанційної роботи показала, що у певної кількості студентів немає бажання навчитися працювати на різних платформах. Вони ледве осягнули Messenger, оскільки були обізнані 3 Facebook. По-четверте, часто-густо домінує брак культури $з$ боку окремих студентів під час проведення онлайн-занять. Вони запізнюються (тобто приєднуються до пари із запізненням), не виконують домашні завдання. Бажання списати і ввести в оману викладача стають для них майже нормою, вони дуже галасливі та нетерплячі, не мають поваги до педагога і своїх колег; сильніші студенти намагаються відповідати замість слабших. Часто під різними приводами не вмикаються камери, а тому не зрозуміло, хто насправді працює і як оцінити такого студента. По-п'яте, робота 3 онлайн-матеріалами використовується недостатньо, бо студенти часто не вміють (або не хочуть) працювати самостійно 3 книгою, особливо якщо немає перекладу рідною мовою. При цьому знання багатьох англійської мови також дуже низькі. Робота в першому семестрі відбувається за посібником «Крок-2 (рівень В1)» (Палінська, 2014: 160). 3 огляду на вищеперераховані реалії часто доводиться повертатися до цієї книги і у подальшому, оскільки повноцінне засвоєння нового матеріалу, передбаченого програмою, стає в такій ситуації проблемою.

Дистанційний навчальний процес у групах студентів другого курсу перетворюється переважно на короткі відеоуроки, під час яких викладач встигає лише повідомити їм стислу інформацію, перевірити домашнє завдання та (нерідко) провести виховну бесіду. На пояснення граматичних тем, читання часу часто просто не вистачає. Для того, щоб якось вирішити проблему, студентам на Messenger надсилаються потрібні світлини 3 книги. Попередньо вони слухають інструкцію 3 виконання вправ із вказаними номерами. Дається певний час (15-20 хв.) на виконання і тоді робота триває далі. Рятує те, що студенти живуть разом (по декілька людей в кімнаті), і можуть використовувати один девайс для спілкування, а інший для перегляду матеріалу. При цьому багато студентів немає комп'ютера чи ноутбука (лише смартфони), що, знову ж таки, створює додаткові труднощі. 3 урахуванням ситуації часто ми змушені для роботи підбирати простіші матеріали, зокрема нами використовується посібник «Українська мова для іноземців. Крок за кроком» (Мазурик, 2017: 288).

Пропонуємо для ознайомлення перелік завдань, які стали основними для роботи зі згаданою категорією іноземних студентів під час дистанційного навчання. Письмові вправи: 1) на заповнення пропусків - іменники істоти та неістоти 3 питаннями Хто? / Що?, із використанням малюнків; 2) дописати слово у відповідному роді. Повторення роду іменника; 3) дописати закінчення. Повторення кличного відмінка; 4) підкреслити слова. Повторення числа іменника (однина і множина); 5) вписати слова у три колонки, відповідно до відмінкових закінчень роду іменника; 6) прочитати і надписати над словами рід і число іменника; 7) доповнити таблицю прикладами 3 довідки. Повторення особових займенників мій, моя, моє, мої; твій...; 8) замість крапок поставити мій, моя, моє, мої...; 9) закінчити речення за зразком: ие мій ... / це мій брат; 10) перепишіть слова, вставляючи пропущені букви, і визначте рід: кім...ата (...) - кімната (ж.р.); 11) утворити форми множини від поданих іменників: університет - університети...; 12) утворити форми множини від іменників та підкреслити букви, що позначають звуки, які зникають або змінюються: палець - пальиі...; 13) дати відповіді на питання, використавши слова в дужках: Яка ие cmona? (великий) - Це велика стопа; о) записати прикметники у потрібній формі: молодий, $a, e, i$ (студент, дівчина, хлопці); 14) записати словосполучення у множині: новий гуртожиток - нові гуртожитки; $15)$ описати портрет людини на фото, свій портрет, портрет свого друга, чи подруги; повторення теми характеристики людини тощо. Вправа на читання: 1) таблиці із особовими займенниками я, ти він, вона, воно, ми, ви, вони, відповідно до питань Чий?, Чия, Чиє?, Чиї?; 2) вивчення прикметника і ознайомлення з антонімами (високий - 
низький); питання до прикметника (Який?, Яка?, Яке?, Які?); рід прикметника тощо.

Упродовж семестрів, які пройшли в умовах дистанційного навчання, нами опрацьовувалась зі студентами велика кількість письмових вправ i завдань. Значно менше часу ми змогли приділити завданням на слухання та говоріння. Не дали очікуваного результату завдання на вивчальне та ознайомлювальне читання. У дистанційному режимі студенти їх, практично, не сприймають, не працюють зі словником, не формують свої словники і коментарі до текстів тощо. Вони всіляко намагаються використати Googl-перекладач для всього тесту, зрозуміти, загалом, його рідною мовою і на цьому зупинитись, не запам'ятовуючи жодного нового слова. Натомість, як відомо, за умови проведення заняття в аудиторії, цьому виду роботи приділяється багато часу і зусиль. Під час дистанційного навчання студенти також гірше сприймають інформацію, часто спостерігаються спроби одночасного читання і відповідей декількох 3 них, що призводить до сильного спотворення звуків і вимови слів. У перший період дистанційної роботи нам доводилось витратити багато часу, щоб побороти у студентів страх перед самостійними відповідями. Кожного студента доводилось іноді слухати по два-три рази.

Загалом, дистанційна форма помітно пригальмувала процес навчання, а у таких умовах робота на платформі Zoom (якщо вона обмежена у часі) взагалі дає поганий результат. Якщо врахувати всі вищезазначені моменти, то можна сказати, що кількість недоліків під час онлайн-навчання переважила у другокурсників кількість набутих ними чітких практичних умінь i навичок. Осягнути університетську програму, використати повною мірою платформу ВНС вони так і не змогли.

Разом із тим упровадження дистанційних занять з української мови для студентів-іноземців різних курсів і спеціальностей відбувалось на практиці дуже неоднорідно. Для багатьох (представники Еквадору, Конго, Азербайджану, Марокко; спеціальності: прикладна математика, біотехнології, архітектура, туризм, кібербезпека, біоінженерія, міжнародні відносини) це було хорошим випробуванням. Вони змогли активно згрупуватись у Viber-i та Messenger-i, вели переписку щодо організації та проведення занять. Робота тривала злагоджено та за розкладом, сформованим на початку семестру (звичайно ж, 3 невеликими корективами). Студенти допомагали одне одному, використовуючи всі можливі мови спілкування. Зрозуміло, що більше часу вони займалися самостійно (зокрема, виконуючи письмові завдання та вправи на читання), оскільки через неякісний зв'язок ми не завжди могли їх добре чути і бачити. Але основні граматичні теми та слухання ми практикували разом саме під час дистанційних занять. Із завданнями у ВНС більшість іноземців (хоча, як ми вже зазначали вище, не всі) впорались, загалом, непогано, що свідчить про їхню готовність до нових умов навчання.

Висновок. Стрімка інтеграція дистанційної форми навчання в освітній процес, зумовлена запровадженням карантинних обмежень, стала серйозним поштовхом для іiі подальшого розвитку. Немає також сумніву в тому, що реалії, в яких ми сьогодні опинились, стануть добрим стимулом для розвитку творчих та креативних можливостей українських викладачів. Саме у процесі апробації і опрацювання певних методичних розробок чітко вимальовується та схема, яка зможе допомогти студентам-чужоземцям вивчити мову та спрямувати викладачів на пошук найрізноманітніших методів викладу і подачі мовного матеріалу. Дистанційні заняття стали одним із напрямків для вирішення важливих проблем у проведенні практичних занять з української мови як іноземної. Вони дають можливість розвивати аналітичні здібності, винахідливість і компетентність студентів, несуть у собі значний виховний потенціал, а також є засобом підвищення мотивації до вивчення предметів, оскільки створюють умови для практичного застосування знань та розвивають навички самоосвіти. Та навіть досконало продумане заняття завжди буде мати певні недоліки, уточнення тощо. Тому лише у спілкуванні і пізнанні потреб студента викладач може досягти істини.

\section{СПИСОК ВИКОРИСТАНИХ ДЖЕРЕЛ}

1. Дзеньдзюра Н. Словник словотвірних гнізд як один із засобів вивчення української мови як іноземної. Теорія і практика викладання украӥнської мови як іноземної : зб. наук. пращьь. Львів : Видавничий центр ЛНУ ім. І. Франка, 2014. Вип. 10. С. 79-84.

2. Козелко І. І. Вивчення фонетики в іншомовній аудиторії. Теорія і практика викладання украӥнської мови як іноземної : зб. наук. пращьь. Львів : Видавничий центр ЛНУ ім. І. Франка, 2015. Вип. 11. С. 126-130.

3. Куньч 3. Й. Системне вивчення науково-технічної термінології у роботі зі студентами-іноземцями. Теорія $i$ практика викладання украӥнської мови як іноземної. Львів : Видавничий центр ЛНУ ім. І. Франка, 2008. Вип. 3. C. $198-202$. 
4. Лещенко Т. О. Формування лінгвокраїнознавчої компетенції іноземних студентів медичних ВНЗ засобом української пісні. Т.О. Лещенко, І.В. Самойленко, В.Г. Юфименко. Творчість Райси Кириченко в культурному просторі України на покордонні XX-XXI століть: до 70-ліття від дня народження Берегині української пісні : зб. наук. працьь. Полтава : ПНПУ імені В.Г. Короленка, 2013. С. 253-261.

5. Мазурик Д. В. Українська мова для іноземців. Крок за кроком. Львів : Фоліо, 2017. 288 с.

6. Мельник I. В. Методика проведення бінарних уроків як одної з форм реалізації міжпредметних зв'язків. 2015. URL : https://www.slideshare.net/ inessaml/ss-44178834 (дата звернення: 27.01.2020).

7. Мончук О. Уроки в режимі онлайн, або Як івано-франківські школи працюють у форматі дистанційного навчання? 2020. URL: https://galychyna.if.ua/analytic/uroki-v-rezhimi-onlayn-abo-yak-ivano-frankivski-shkoli-pratsyuyutu-formati-distantsiynogo-navchannya/ (дата звернення: 26.01.2021).

8. Палінська О. М. Крок-2 (рівень В1). Українська мова як іноземна : книга для студента. Львів : Дон Боско, 2014. $160 \mathrm{c}$.

9. Палінська О. М. Крок-2 (рівень В1). Українська мова як іноземна : робочий зошит. Львів : Дон Боско, 2014.56 с.

10. Палінська О. М., Туркевич О.Р. Крок-1 (рівень А1-А2). Українська мова як іноземна: книга для студента. Львів : Артос, 2011, 2014. 100 с.

\section{REFERENCES}

1. Dzendziura N. Slovnyk slovotvirnykh hnizd yak odyn iz zasobiv vyvchennia ukrainskoi movy yak inozemnoi [Dictionary of word-forming nests as one of the means of studying Ukrainian as a foreign language]. Teoriia $i$ praktyka vykladannia ukrainskoi movy yak inozemnoi : zb. nauk. prats. Lviv: Vydavnychyi tsentr LNU im. I. Franka, 2014. Vyp. 10. S. 79-84 [in Ukrainian].

2. Kozelko I. I. Vyvchennia fonetyky v inshomovnii audytorii [Studying phonetics in a foreign language audience]. Teoriia i praktyka vykladannia ukrainskoi movy yak inozemnoi : zb. nauk. prats. Lviv: Vydavnychyi tsentr LNU im. I. Franka, 2015. Vyp. 11. S. 126-130 [in Ukrainian].

3. Kunch Z. I. Systemne vyvchennia naukovo-tekhnichnoi terminolohii u roboti zi studentamy-inozemtsiamy [Systematic study of scientific and technical terminology in working with foreign students]. Teoriia i praktyka vykladannia ukrainskoi movy yak inozemnoi. Lviv: Vydavnychyi tsentr LNU im. I. Franka, 2008. Vyp. 3. S. 198-202 [in Ukrainian].

4. Leshchenko T. O. Formuvannia linhvokrainoznavchoi kompetentsii inozemnykh studentiv medychnykh VNZ zasobom ukrainskoi pisni [Formation of linguistic competence of foreign students of medical universities by means of Ukrainian song]. T. O. Leshchenko, I. V. Samoilenko, V. H. Yufymenko. Tvorchist Raisy Kyrychenko v kulturnomu prostori Ukrainy na pokordonni KhKh-KhKhI stolit: do 70-littia vid dnia narodzhennia Berehyni ukrainskoi pisni : zb. nauk. prats. Poltava: PNPU imeni V. H. Korolenka, 2013. S. 253-261 [in Ukrainian].

5. Mazuryk D. V. Ukrainska mova dlia inozemtsiv. Krok za krokom [Ukrainian language for foreigners. Step by step]. Lviv: Folio, 2017. 288 s. [in Ukrainian].

6. Melnyk I. V. Metodyka provedennia binarnykh urokiv yak odnoi z form realizatsii mizhpredmetnykh zviazkiv [Methods of conducting binary lessons as a form of implementation of cross-curricular relations]. URL: https://www.slideshare.net/ inessaml/ss-44178834 (data zvernennia 27.01.2020).

7. Monchuk O. Uroky v rezhymi onlain, abo Yak ivano-frankivski shkoly pratsiuiut u formati dystantsiinoho navchannia? [Online lessons, or How do Ivano-Frankivsk schools work in the format of distance learning?]. 2020. URL: https://galychyna.if.ua/analytic/uroki-v-rezhimi-onlayn-abo-yak-ivano-frankivski-shkoli-pratsyuyut-u-formatidistantsiynogo-navchannya/ (data zvernennia 26.01.2021).

8. Palinska O. M. Krok-2 (riven V1). Ukrainska mova yak inozemna: knyha dlia studenta [Step-2 (level B1). Ukrainian as a foreign language: a book for students]. Lviv: Don Bosko, 2014. 160 s. [in Ukrainian].

9. Palinska O. M. Krok-2 (riven V1). Ukrainska mova yak inozemna: robochyi zoshyt [Step-2 (level B1). Ukrainian as a foreign language: workbook]. Lviv: Don Bosko, 2014. 56 s. [in Ukrainian].

10. Palinska O. M., Turkevych O. R. Krok-1 (riven A1-A2). Ukrainska mova yak inozemna: knyha dlia studenta [Step-1 (level A1-A2). Ukrainian as a foreign language: a book for students]. Lviv: Artos, 2011, 2014. 100 s. [in Ukrainian]. 